\title{
Entre o amargor e a doçura: as imagens literárias da vespa e da abelha em poemas de Gilka Machado e Juana de Ibarbourou
}

\author{
Between bitterness and sweetness: the literary images of the wasp \\ and the bee in Gilka Machado's and Juana de Ibarbourou's poems
}

\section{Entre el amargor y la dulzura: las imágenes literarias de la avispa y de la abeja en poemas de Gilka Machado y Juana de Ibarbourou}

Lina Arao*

lina_arao@hotmail.com

Universidade Federal do Rio de Janeiro

RESUMO: Em um cenário de mudanças, como o que marcou o final do século XIX e início do XX na América Latina, as mulheres vão ganhando alguma abertura para uma incipiente participação no âmbito público, mas ainda permanecem os cerceamentos sociais e políticos, principalmente no tocante ao corpo feminino. Nesse contexto, surgem importantes obras poéticas de autoras que, embora conhecidas, não receberam, por muito tempo, uma maior atenção dos estudos acadêmicos, como a brasileira Gilka Machado e a uruguaia Juana de Ibarbourou. Este texto propõe apresentar, à luz da ginocrítica, sobretudo através das considerações de Sandra Gilbert e Susan Gubar, uma leitura comparativa entre dois poemas - "Beijo" e "Las cuatro alas de abeja" -, cada qual pertencente ao livro de estreia das respectivas poetisas, levando em conta figuras literárias presentes nas duas composições - a da vespa e da abelha. A partir dessas imagens, constrói-se uma subjetividade poética cujas relações com o erotismo e a sensualidade apresentam contornos oscilantes.

PALAVRAS-CHAVE: Gilka Machado. Juana de Ibarbourou. Literatura de autoria feminina.

ABSTRACT: In a scenario of change, such as the one in Latin America at the end of the 19th century and the beginning of the 20th century, society starts to be open to women's participation in the public sphere; however, they are still socially and politically constrained, especially in relation to the female body. In this context, relevant poetic works by female authors emerge. Although the works by the Brazilian author Gilka Machado and the Uruguayan author Juana de Ibarbourou are known by

\footnotetext{
* Pós-doutoranda em Ciência da Literatura (Literatura Comparada) pela Universidade Federal do Rio de Janeiro.
} 
the public, for example, they were not the object of academic studies for a long time. Based on gynocriticism, especially Sandra Gilbert's and Susan Gubar's remarks, this article aims to present a comparative reading of two poems, viz., "Beijo" and "Las cuatro alas de abeja." The poems, which are in the debut works of the respective poets, take into account the literary images that are present in the poems - the wasp and the bee. Stemming from these images, a poetic subjectivity is constructed whose relations with eroticism and sensuality present oscillating contours.

KEYWORDS: Gilka Machado. Juana de Ibarbourou. Literature of female authors.

RESUMEN: En un escenario de cambios, como lo que señaló el final del siglo XIX e inicio del $\mathrm{XX}$ en Latinoamérica, las mujeres logran alguna apertura para una incipiente participación en el ámbito público. Sin embargo, todavía se mantienen las limitaciones sociales y políticas, sobre todo en cuanto al cuerpo femenino. En ese contexto, surgen importantes obras poéticas de autoras que, aunque conocidas, no recibieron, por un largo tiempo, mucha atención de las investigaciones académicas, como la brasileña Gilka Machado y la uruguaya Juana de Ibarbourou. En este texto se propone presentar, a través de la ginocrítica (sobre todo las ideas de Sandra Gilbert y Susan Gubar), una lectura comparativa entre dos poemas - "Beijo" y "Las cuatro alas de abeja" -, pertenecientes a los libros de estreno de las respectivas poetisas, teniendo en cuenta figuras literarias presentes en las dos composiciones la de la avispa y de la abeja. Desde esas imágenes, se construye una subjetividad poética cuyas relaciones con el erotismo y la sensualidad presentan contornos oscilantes.

PALABRAS CLAVE: Gilka Machado. Juana de Ibarbourou. Literatura de autoría femenina.

\section{Palavras iniciais: observações sobre o contexto sociocultural}

O final do século XIX e as primeiras décadas do século XX apontaram para diversas mudanças socioculturais e científico-tecnológicas, que acabaram por atingir também a América Latina, preocupada em modernizar-se a partir de um ímpeto técnico e cientificista de matrizes norte-americana e europeia, inserindo sua economia nos moldes da produção capitalista. Tais transformações foram mais intensas nas capitais latino-americanas, como Rio de Janeiro e Montevidéu, para onde o influxo de migrantes e imigrantes era especialmente abundante. As reformas urbanas e sociais faziam parte de um projeto de disciplinamento e de "higienização", buscando os "ares civilizatórios" que marcariam a distinção das novas repúblicas com relação ao "passado", não tão distante, da colônia e, no caso do Brasil, da monarquia. A maior facilidade de movimentação pela cidade, lograda pelas inovações tecnológicas relativas aos transportes, juntamente com a industrialização 
permitiram uma pequena abertura para a introdução de mulheres no espaço público urbano, através de algumas novas perspectivas de trabalho e atuação fora do âmbito doméstico, conforme indica Margareth Rago (2011, p. 585). No entanto, ao mesmo tempo, em reação a essa moderada modernização da vida social feminina, ressaltaram-se discursos moralizadores que destacavam o papel social das mulheres na manutenção das famílias - a "mãe cívica", responsável pela criação dos futuros cidadãos.

A sexualidade feminina, em consequência, continuava vigilada: a castidade das mulheres era ainda condição indispensável e deveria ser preservada antes do casamento. Como revela a historiadora Rosa Maria Barboza de Araújo, "o conceito de honra feminina está ligado à castidade. A perda de virgindade cria uma barreira para a inserção social da mulher, levando-as muitas vezes ao suicídio" (1995, p.89). Até mesmo as viúvas deveriam guardar o recato em nome de seus falecidos maridos, sendo a família uma das responsáveis por "proteger" as mulheres dos "males" da vida pública e mundana, assim como a própria Igreja Católica, que continuava sendo um instrumento eficaz na preservação da "moralidade" feminina. Os tempos de mudança que concediam uma moderada e controlada permissão à tímida saída das mulheres em direção ao espaço público foram, assim, marcados por um discurso profundamente segregador e delimitador das atividades femininas: às mulheres ainda era exigida a sua permanência na casa, alegando-se uma (fictícia) natureza abnegada, que se satisfaria em cuidar dos outros. Enquanto isso, aos homens destinava-se o espaço aberto do público e das atividades políticas, intelectuais e literárias. Como observam Marina Maluf e Maria Lúcia Mott (2012, p. 385), "não é sem desconfiança que lemos sobre a intensidade e velocidade das mudanças nas vidas das mulheres brasileiras. Algumas décadas não foram suficientes para influenciar tão fortemente a mulher [...] e arrastá-la para 'viver com o mundo e para ele' [...]". O período compreendido entre fins do século XIX e inícios do subsequente pareceu confrontar duas formas de pensamento: diante das modificações trazidas pelos ventos modernos, particularmente nas grandes cidades como o Rio de Janeiro, tentou-se fortificar uma moralidade tradicional.

No caso de Montevidéu, a equação mulher-família-nação era bastante similar: se esses dois últimos elementos, desde o século XIX, segundo afirma María Inés de Torres (2013, p.41-42, tradução nossa), eram "articulações simbólicas correlativas", em que a primeira configurava o lugar da ordem e da autoridade, instituição 
necessária para "expressar a tão necessitada paz social", a mulher-mãe adquiria a importante função de preservar a saúde e a educação dos filhos e, por conseguinte, de formar aqueles que serão indispensáveis na consecução do projeto civilizatório de uma nação culta, saudável e ordenada. Nesse contexto, as teorias associadas à eugenia dedicaram-se principalmente às mulheres: o discurso conservador (médico, religioso, pedagógico) de preservação da "moral" e da castidade buscava "protegêlas" das relações consideradas inadequadas e perigosas (sexualidade que poderia levar ao contágio de doenças venéreas, o "problema" da mestiçagem), preservando e insistindo na ocupação por parte delas da função "natural" da maternidade. Tais preocupações sanitaristas camuflavam, como assinala Graciela Sapriza (2008, p.890, tradução nossa), "os temores que suscitava a modernização e o impacto emancipador sobre as mulheres": se, por um lado, reformas políticas, econômicas e sociais (no caso do Uruguai, por exemplo, criou-se a Lei do Divórcio em 1907) ofereceram alguns ganhos no tocante aos direitos femininos, por outro lado, os papéis sociais impostos a elas como funções "naturais" e obrigatórias limitavam as possibilidades reais de emancipação, uma vez que elas continuavam responsáveis pelo cuidado da família (o que se opunha a um trabalho fora do âmbito doméstico), impedidas de ter acesso à educação formal nos moldes masculinos e aos plenos direitos civis. Como destaca Carina Blixen (2014, p.165, tradução nossa) ao tratar do Uruguai do início do século XX, havia um "hiato entre uma racionalidade progressista (que queria atuar sobre a realidade para transformá-la) e a vida dos homens e mulheres desse tempo."

Para as mulheres escritoras, o contexto de criação e recepção de suas obras era igualmente contraditório: além do fato de que elas não tinham acesso livre ao território público, como o caso dos bares, restaurantes e cafés frequentados pelos escritores homens, nos quais se reuniam e onde se operava uma importante troca de conhecimentos e experiências, constituindo, segundo Blixen (2014, p.94, tradução nossa) um "fermento determinante da atividade intelectual dos homens", restando a elas as reuniões dentro de suas casas, quando sua situação econômica e social Ihes permitia, as escritoras tinham mais frequentemente à disposição imagens literárias femininas criadas pelos homens. Ainda durante a modernização, que, no Uruguai, por exemplo, permitiu uma espécie de "revolução erótica" (o caso do escritor dandy, conforme observa Blixen), o ideal feminino seguiu sendo o da subordinação entre os gêneros, o da separação entre uma mulher "decaída" e uma 
"honrada" e o da mulher objeto do desejo e do olhar masculino. O exercício de construção de uma subjetividade e de um sujeito poético feminino criador era, dessa maneira, complexo e, muitas vezes, incidia em contradições - as máscaras sociais impostas (as de filha, irmã, esposa, mãe, viúva) confrontavam-se com a da escritora, nem sempre compreendida e geralmente lida através de uma crítica paternalista (uma vez que era predominantemente masculina no começo do século $X X$ ), que buscava escamotear traços "desviantes" da norma, como o erotismo e a sensualidade, quando não a censurava pelos mesmos motivos.

Interessa atentar, nesse sentido, para uma observação referida por Blixen (2014, p.98), a partir da qual afirma que durante esse período de final do século XIX e início do subsequente a profissionalização do intelectual ocorreu concomitantemente a uma marginalização da arte no âmbito da divisão do trabalho. A pesquisadora (2014, p.98, tradução nossa), então, supõe que, quando a arte se transforma em "adorno passageiro ou extravagante, [...] pode ser um reduto para a mulher". Como atividade pouco ou nada remunerada, constituindo um espaço cultural ambíguo, que poderia inclusive ser feita dentro dos limites domésticos, a escrita passa a ser moderadamente permitida às mulheres. Essa circunstância, no entanto, aprofunda as contradições, já que as escritoras ainda precisavam conciliar a arte com as funções sociais consideradas "naturalmente" femininas e com os paradigmas acerca do ideal feminino, o que as impedia de livremente expressaremse pela literatura, de modo que assumiam várias facetas ou escondiam recônditos de suas subjetividades sob as máscaras sociais exigidas. Assim, nessa época de transições, surgiram diversas célebres escritoras na América Latina: na historiografia literária hispano-americana, por exemplo, há referências às "vozes femininas do pósmodernismo" ${ }^{1}$, poetisas como as uruguaias Delmira Agustini (1886-1914) e Juana de Ibarbourou (1892-1979), a argentina Alfonsina Storni (1892-1938) e a chilena Gabriela Mistral (1889-1957). No Brasil, Gilka Machado (1893-1980) começou a

\footnotetext{
${ }^{1}$ É preciso atentar para o fato de que o "modernismo" hispano-americano não corresponde ao "modernismo" brasileiro, sendo mais equiparável ao nosso simbolismo. "Pós-modernismo" é um termo controverso e de difícil definição, visto que, de acordo com Luis Sáinz de Medrano (2008, p.483, tradução nossa), é uma "situação que se produz na poesia hispânica quando o Modernismo [...] perde por lei natural seu impulso [...] e sem renunciar suas conquistas, entende que 'a religião da Arte' se mostra insuficiente para refletir sobre os grandes problemas humanos". Alguns dos aspectos detectáveis no "Pós-modernismo" são, segundo o mesmo crítico, "a simplicidade lírica, a visão da cidade com seus subúrbios, a ironia sentimental [...]" (SÁINZ DE MEDRANO, 2008, p.484, tradução nossa).
} 
publicar suas poesias em um período bastante próximo, em um contexto sociocultural também similar ao das autoras hispano-americanas citadas.

Como poetisas nascidas em sociedades latino-americanas de formação católica no momento de transições no campo sociopolítico, econômico e cultural do final do século XIX, cuja produção lírica percorreu um longo caminho pelo século $X X$, Juana de Ibarbourou e Gilka Machado expressaram as complexidades no que concerne à afirmação e à expressão poética, revelando, frequentemente, estratégias semelhantes para a construção da subjetividade poética, podendo-se rastrear em suas manifestações artísticas traços como o erotismo e a sua relação com elementos da natureza e representações simbólicas de limitação da liberdade e das possibilidades de expansão. Neste texto, objetiva-se propor uma análise comparativa de dois poemas: "Las cuatro alas de abeja", constante do primeiro livro de poemas de Juana de Ibarbourou - Las lenguas de diamante (1919) -, e "Beijo", composição da primeira obra de Gilka Machado - Cristais partidos (1915). Além de pertencerem ambos aos respectivos livros de estreia, os textos líricos referem-se à experiência do beijo e às sensações que causa no sujeito poético feminino através de metáforas entre as quais se inclui a imagem da abelha/vespa, desde aspectos acerca dos quais este ensaio intentará discutir.

\section{Sobre a simbologia relacionada com a abelha: algumas apreciações}

A imagem da abelha tem estado presente desde a tradição literária clássica, adquirindo diversos sentidos ao longo dessa história, uma vez que tanto o inseto quanto o mel foram fundamentais para o desenvolvimento de variadas civilizações. Rachel Carlson (2015) explica que a abelha representa um importante papel na mitologia greco-romana, revelando complexos e múltiplos significados. Sendo uma criatura alada, está associada ao divino, aos céus, ao mesmo tempo em que, como pode construir sua morada em cavidades nas árvores, nas pedras ou dentro de cavernas, fica muitas vezes escondida dos olhos humanos; desse modo, ela estava relacionada, para gregos e romanos, ao âmbito do celestial e do terreno concomitantemente, e, mais do que isso, era capaz de cruzar ambas as esferas, borrando os limites entre elas (mundo dos vivos e o dos mortos, a esfera divina e a humana) (Cf. Carlson, 2015, p.20). Carlson (2015, p.26, tradução nossa) afirma que o filósofo neoplatônico Porfírio, corroborando a ideia de Sófocles, considerava a 
abelha como um emblema para as almas que viveriam de forma justa, associando-a ao nascimento das almas e acrescentando a noção de que o mel é um "símbolo da morte [...], mas também conectado com a geração [...], a purificação [...] e os prazeres da cópula [..]". As estátuas de Éfeso da deusa Ártemis representam-na com abelhas ao redor de suas pernas, além de que em moedas dessa mesma cidade também figuram imagens do animal. Ademais, as sacerdotisas associadas com Ártemis e Deméter eram chamadas de Melissai, demonstrando sua relação com as abelhas: os motivos de tais associações, conforme indica Carlson (2015, p.37), podem ser diversos, mas existe uma conexão entre as abelhas (fortemente ligadas à fertilidade e à vegetação) e essas deusas que simbolizam a fertilidade e o mundo natural. Kristen M. E. Stillwell destaca outra importante presença dos insetos na mitologia grega: quando Rhea esconde seu filho Zeus em uma caverna, o bebê é alimentado com mel, que permanece sendo um dos alimentos preferidos pelos deuses gregos. Carlson, por sua vez, reforça o vínculo entre Zeus e as abelhas citando diversos episódios mitológicos em que elas surgem, por vontade dele, para alimentar um de seus filhos com uma ninfa seduzida, fazendo do mel uma espécie de substituto para o leite materno.

A pesquisadora ainda observa que, por ser a "revelação da vontade divina de Zeus e a manifestação do conhecimento de outro mundo na terra - [...], - a ligação entre poesia, profecia e a abelha não é surpreendente" (CARLSON, 2015, p.43, tradução nossa) e funciona em vários níveis. Stillwell (2012) também ressalta que se acreditava que o mel era a fonte de inspiração divina, tendo muitos dos filósofos e oradores atribuído suas habilidades ao fato de que abelhas pousaram sobre suas bocas durante a infância (Cf. Stillwell, 2012, p.7-8). Por outro lado, a tradição literária clássica pode apresentar outra noção para a figura da abelha: Carlson (2015, p.111114) destaca um fragmento escrito por Safo preservado por Trifão, cuja contextualização se perdeu - "para mim, nem o mel nem a abelha". De acordo com ele, essa frase seria um provérbio, que, conforme Diogeniano, estava relacionado com a ideia de que um indivíduo poderia rechaçar algo positivo por causa do mal que viria com ele, isto é, uma experiência boa poderia conter outra negativa, de modo que não haveria possibilidade de separar as duas partes: dentro da colmeia, guardada por abelhas combativas, existe o mel - o tesouro apenas será desvendado e conquistado através do risco do sofrimento e do esforço. Se cotejarmos essa ideia com a temática erótica e amorosa presente no trabalho de Safo, podemos cogitar a 
avaliação de que o sujeito poético prefere evitar a doçura (o "mel") do prazer amoroso/erótico para também escapar das ameaças dos ferrões (a "abelha"), da dor que esse mesmo sentimento traz ao amador. A natureza mista da paixão erótica/amorosa surge de forma semelhante em outros poetas gregos, segundo observa Carlson, como em uma das composições líricas da Anacreontea que apresenta o primeiro encontro de Eros ainda criança com uma abelha que o pica. Eros corre para sua mãe, Afrodite, para lamentar sobre a dor que sofria, obtendo o comentário materno de que o sofrimento causado pela pequena abelha é muito menor do que o que ele mesmo inflige naqueles que atinge com suas flechadas. Assim, com o mel e os prazeres do amor, há os sofrimentos e os problemas que eles trazem consigo: em uma via de mão dupla, não se pode escapar do mal quando se almeja desfrutar os benefícios do contentamento no que concerne a relações amorosas.

Carlson (2015, p. 117-122) destaca que as imagens da abelha e da colmeia são também utilizadas metaforicamente para ilustrar a relação entre homens e mulheres por Hesíodo: assim como os zangões ficam na colmeia apenas alimentando-se do trabalho árduo das abelhas, as mulheres também se aproveitariam da labuta das "abelhas-homens". Entretanto, essa relação considerada desigual pelo grego seria inevitável, uma vez que os homens precisavam das mulheres para continuar suas linhagens e criar herdeiros que pudessem ajudá-los nos trabalhos. Dessa maneira, novamente surge a ideia de que para se obter o mel há que se enfrentar as ferroadas das abelhas - junto com os benefícios, vêm os malefícios, a colmeia/casa precisa dos "trabalhadores" e dos "aproveitadores", uma imagem "literária" da representação masculina da mulher, indicando o machismo e a misoginia então marcadamente presentes na cultura clássica. Fica ainda implícita uma implicação erótica nessa concepção da mulher e de sua associação com o homem: o intercurso sexual também era visto em sua desigualdade, já que, nessa perspectiva, a mulher "roubaria" a substância masculina, sendo representada como a mescla do benéfico e do demoníaco - a fim de receber os prazeres sexuais e a promessa de filhos, os homens ficariam supostamente privados de parte de seus recursos econômicos e sexuais. Desse modo, para Carlson (2015, p. 122, tradução nossa), "o uso de Hesíodo da imagem da abelha oferece meios para expressar tanto o econômico quanto o erótico, que eram provavelmente já parte das conceptualizações usais sobre a colmeia". 
A imagem dual relacionada com a abelha surge também no cristianismo, segundo Udo Becker, Jean Chevalier e Alain Gheerbrant: conforme o primeiro, a abelha seria um símbolo de Cristo - o "mel representa a gentileza e a compaixão de Cristo, enquanto o ferrão representa Cristo como o juiz do mundo" (BECKER, 2000, p. 38, tradução nossa). Chevalier e Gheerbrant (1986, p.42, tradução nossa) acrescentam a simbologia evocada pelo corpo da abelha: a parte superior "é a imagem do homem espiritual, enquanto que a parte inferior, que contém o ferrão, é considerada carnal. A parte mais fina que une a superior e a inferior se compara ao ponteiro da balança que mantém um perfeito equilíbrio entre corpo e alma". Ambos também relatam a associação da abelha certas vezes feita com a castidade (e, de acordo com Becker, com a Imaculada Conceição) devido à crença antiga de que elas não procriavam sexualmente, mas surgiam das flores, reforçando a faceta espiritual da figura simbólica. Todavia, as ambivalências parecem predominar no que concerne à simbologia relacionada com a abelha, tanto na tradição cultural e literária clássica, quanto na derivada do cristianismo. As múltiplas noções conectadas ao inseto frequentemente têm origem e motivação pouco conhecidas, podendo também ser relacionadas com culturas não ocidentais e outras mais antigas que a greco-romana, o que torna o assunto extremamente complexo e extenso, sendo inviável uma análise plena em um texto de pequenas dimensões. Este ensaio propõe apenas mencionar algumas das imagens associadas à simbologia muitas vezes presente em textos de autoria feminina, como nos poemas de Juana de Ibarbourou e Gilka Machado, buscando compreender a importância dessas imagens na poesia das duas escritoras e sugerindo uma leitura possível para as duas composições líricas.

\section{Uma possível leitura dos poemas "Beijo" e "Las cuatro alas de abeja"}

O poema "Beijo" menciona um inseto associado à abelha - a vespa:

Beijo, beijo de amor - ave em cuja asa crespa o espírito se eleva a paragens etéreas, ignívoma, nervosa e zumbidora vespa, que infiltra nas artérias da volúpia o fervente e orgíaco veneno; som que ao festivo som de um guizo se assemelha, que a um só tempo gemido, é gargalhada e é treno; 
semente, que a vermelha

flor da luxúria vem plantar sobre o maninho

solo da alma; licor que se contém da boca

na ânfora coralina, espiritual carinho;

bala rubra que espoca

no lábio; arredondada e rútila e sonora

frase que vem narrar do amor todo o áureo poema,

e que entender só pode o ente que ama, que adora.

Beijos de amor - suprema

delícia, original pomo da árvore da alma,

cujo galho, a subir, vai pender sobre a ameia

do lábio, pomo que ora excita e que ora acalma.

Dentro, em nós, mais se ateia,

ao contato febril do lábio amado e amante,

das ânsias a fogueira, e dos beijos o ruído

ser julgo o crepitar desse fogueira estuante.

Beijo de amor - olvido

para os males da ausência; astro canoro e rubro

que no horizonte arcoal do lábio humano aponta;

flor que adorna do afeto o suntuoso delubro;

aurifulgente conta

que, ó Alma! vais enfiar no colar dos prazeres:

rumor que, em si, contém cintilas policores,

sonora confusão das bocas e dos seres;

misto de sons e odores,

beijo, beijo de amor - escandalosa loa,

que, na festa pagã do luxuriante gozo,

em louvor a Cupido a humana boca entoa.

Elixir delicioso,

que ao paladar nos traz da saudade os ressábios;

remédio com que, ó Ânsia! esse teu mal ensalmas;

beijo, beijo de amor - matrimônio dos lábios

- concubito das almas. (MACHADO, 1978, p. 20-21)

Já vários críticos ressaltaram a musicalidade e o ritmo que emanam dos poemas gilkianos. Nádia Battella Gottlieb (1982, p. 24) observa que, sobretudo em Cristais partidos, verificam-se um "pendor esteticista, na trilha da elaboração do formalismo parnasiano; e recursos de cunho simbolista que the fornecem as 'brechas' para as impulsões sensoriais de caráter liberador", de modo que a própria sonoridade dos versos, alternadamente mais ou menos longos, pode evocar a sensualidade do tema tratado. Angélica Soares (1999, p. 95) corrobora tal ideia e afirma que nesse poema especificamente a conexão erótica é sugerida "pela métrica que alonga os hexassílabos em alexandrinos, e que conta, a todo tempo com o enjambement, mimetizando os transbordamentos emocionais; com as rimas, a aproximarem pelo som os sentidos das palavras, que assim se intensificam". O longo poema, assim, constrói-se como um bloco único em que as imagens metafóricas acerca do beijo e das sensações suscitadas por ele seguem-se sem 
interrupção, revelando a intensidade do frenesi da experiência e intensificando a indissociável percepção com que ela se traduz para o sujeito poético - um ir e vir de sentimentos contraditórios manifestados por características opostas relacionadas ao beijo, principalmente nos primeiros e nos últimos versos.

Antes de tudo, ressalte-se que o poema está centrado especificamente no "beijo de amor", destacado no primeiro verso, deliberadamente particularizado na repetição do vocábulo - "beijo, beijo de amor" -, o que demonstra que não se trata de qualquer tipo de beijo, mas tão somente daquele elemento envolvido, quiçá, em um relacionamento também de amor, isto é, não seria parte de um encontro casual preocupado apenas com as sensações eróticas. No entanto, o eixo principal do poema abrange precisamente esses estímulos sensuais, que originam, por sua vez, noções distintas e contrapostas. Inicialmente, apesar de ser comparado com a ave que pode elevar o espírito às alturas, ao céu, acrescenta-se o adjetivo "crespa" à sua asa: cabe notar que, embora a palavra possa estar relacionada tão somente à textura das penas, pode também aludir à aspereza e conotar, assim, o indômito e o inquietante, o que acaba por se complementar através da imagem seguinte, também referente a um animal - a vespa.

Semelhante à abelha, pertencente à mesma ordem biológica - Hymenoptera -, esse inseto, entretanto, por não produzir mel comestível para humanos, muitas vezes está associado à faceta da combatividade e da agressividade. Hope B. Werness (2006, p. 427) afirma que os gregos, em geral, apreciavam a vespa por seu comportamento guerreiro e, por isso, decoravam seus escudos bélicos com figuras do animal. No entanto, a pesquisadora recupera outras apreciações simbólicas, como a de Aristóteles, para quem, ao contrário da simbologia da abelha, a da vespa não inclui o elemento divino. Já quanto ao cristianismo, Werness indica duas ocorrências: uma em que São Paulo teria comparado a morte a um inseto, provavelmente uma vespa, e outra em que uma vespa ferroando um gafanhoto se converteu em símbolo medieval da vitória de Cristo diante do demônio. Cotejando a simbologia dos dois insetos, a da vespa parece restringir-se ao aspecto do ataque e da força física, ao passo que a da abelha apresenta uma contraparte relacionada com a importância do mel na alimentação e no imaginário das culturas (o poder nutricional, a doçura do alimento).

Levando em conta essas considerações, importa perceber que a escolha da vespa ao invés da abelha para refletir sobre a experiência do beijo pode sugerir que 
ela não envolve a "doçura" do mel, mas o "veneno" instilado pelo ferrão da vespa, aproximando-se, talvez, por outro lado, de uma concepção da abelha e do mel, no dúbio sentido aludido por Safo do bem inseparável do mal: a luxúria, assim, não está conectada com uma sensação percebida como totalmente positiva pelo eu lírico, já que instiga o frenesi, a agitação e o nervosismo incutidos no corpo do sujeito que se torna passivo dos estímulos, ressaltando o âmbito corporal para contrapor-se diretamente com os versos anteriores que se referiam à elevação etérea. $O$ som produzido pelo inseto também evoca componentes contraditórios, visto que é "festivo" e "gargalhada" ao mesmo tempo em que é "gemido" e "treno", reunindo-se, então, a volúpia e a sensualidade do beijo e uma espécie de substância residual de conotação negativa porque associada à tristeza - o "gemido" pode ser de prazer ou de dor, o "treno" é um canto lamentoso e triste.

A junção entre o "elevado" e o "baixo", espírito e corpo, repete-se nos expressivos versos "Beijos de amor - suprema / delícia, original pomo da árvore da alma, / cujo galho, a subir, vai pender sobre a ameia / do lábio, pomo que ora excita e que ora acalma": a referência ao pomo bíblico, que torna Eva a responsável pela queda da humanidade, é ambiguamente subvertida, pois a árvore pertence à alma e seu pomo pode acalmar - distinguindo-se da situação que se coloca aos humanos no Éden - além de excitar. Entretanto, a ideia do decaimento ainda se evidencia pelo contraste entre o "subir" e o "pender", postos lado a lado em um único verso. 0 beijo de amor, como a maçã bíblica, implica um conhecimento "proibido" para a mulher, e ultrapassar esse limite pode levar à perdição que, no caso do poema, não é absoluta, uma vez que a luxúria "excita" e "acalma", configurando-se como um estímulo de múltiplas possibilidades e condutor de variados "conhecimentos", tanto o que edifica quanto o que consome e destrói, confundindo-se ambos na construção de uma identidade poética desejante e afirmativa quanto ao centramento nas sensações eróticas despertadas pelo beijo de amor.

A mesma ambivalência ressurge nos cinco últimos versos, de modo que, em uma espécie de voragem cíclica, parece tratar-se de reafirmar o caráter volátil da volúpia, que se inicia em uma rubra fagulha - campos semânticos relacionados com o calor, o fogo e a cor vermelha são constantes e constituem o eixo mesmo do poema - e se extingue, restando a falta, a carência. O beijo de amor é, por conseguinte, concomitantemente "elixir delicioso" e detentor dos "ressábios da saudade"; a felicidade traz imediatamente a saudade, a marca de sua ausência, 
indicando que todos os benefícios devem ser aceitos com seus complementos negativos a fim de serem totalmente desfrutados. As últimas duas metáforas do poema remetem à conjunção do espiritual com o carnal, que se coloca de forma distinta nos primeiros versos: o matrimônio, união socialmente adequada para as mulheres, vista como parte essencial da função feminina, dá-se entre os lábios, ressaltando o aspecto físico (não considerado no texto em um sentido meramente convencional, dada a ênfase no erotismo do contato com o outro); já as almas unem-se em "concúbito", isto é, uma relação puramente física e sexual entre elementos espirituais.

Sylvia Paixão (1991, p. 138-141), ao analisar a poética gilkiana, afirma que nela muitas vezes se percebe a cisão do ser, dividido em forças contraditórias, em uma "[...] luta entre a carne e o espírito, eixo central da poética de Gilka" (PAIXÃO, 1991, p.141). Em "Beijo", a dualidade do sujeito poético feminino parece estar problematizada sob esse modelo de espiritualidade e carnalidade, sendo significativo o fato de que, a partir do paradigma socialmente construído para a mulher, ela deveria reprimir a sexualidade, já que mesmo nessa época se exigia o recato feminino como signo de seu comportamento sexual controlado e unicamente existente e limitado ao matrimônio. Expressar poeticamente desejos eróticos era uma transgressão para as mulheres, o que custou à poetisa carioca difamações que atingiram inclusive sua família (Cf. Gottlieb, 1982, p. 32). A socialização feminina, assim, impunha-lhes normas específicas de conduta e uma espécie de "treinamento" para que exercessem uma pré-determinada função social, de modo que as mulheres de maneira geral compartilhavam uma série de experiências expressadas de variadas formas em suas literaturas, revelando de quais maneiras elas responderam aos padrões contra os quais se chocaram ou com os quais compactuaram.

Nesse sentido, a teoria de Sandra Gilbert e Susan Gubar (2000, p. 20-36), que demonstra como influenciaram na produção literária de autoria feminina oitocentista de língua inglesa as imagens dicotômicas - anjo (mulher relacionada à domesticidade, abnegação de seus desejos pessoais em prol do cuidado e obediência à vontade familiar) e demônio (aquela que não se submete a todas as regras impostas socialmente) -, criadas e continuamente reiteradas pela tradição literária de autoria masculina, parece continuar relevante ainda no caso das escritoras latino-americanas das primeiras décadas do século XX. Uma leitura possível, entre tantas outras, para a dualidade inerente ao poema "Beijo" pode levar 
em conta a questão da oposição entre esses dois modelos femininos ainda não completamente subvertidos, colocando-se, assim, em constante "combate" o erotismo transbordante e impossível já de ser negado e escamoteado e a repressão a essas sensações implícitas nas alusões à espiritualidade e à elevação às alturas, juntamente com sua contraparte de "queda" e referências ao corpo, além das menções acerca do lado negativo da volúpia - o "veneno" instilado pela vespa e o "mal" da "Ânsia".

A importância simbólica da vespa, então, parece ganhar um sentido interessante ao combinar as múltiplas percepções associadas ao complexo tratamento do erotismo no poema: as asas do inseto remetem à aclamada ascensão aos céus (por sua vez, podem conectar-se com a espiritualidade, com a relação de almas que se estabelece entre o sujeito poético e seu amado, e à subida das sensações no deleite amoroso), ao passo que o veneno do animal imprime uma forte conotação negativa à noção de volúpia, cujo frenesi, por outro lado, é associado aos sons frenéticos de "guizo", produzidos pela vespa. A escolha dela ao invés, por exemplo, da figura da abelha, mais relacionada tradicionalmente pela literatura com o divino e com percepções mais positivas, indicam, porventura, a ênfase nos aspectos mais "obscuros" das sensações eróticas, conotando uma perspectiva não completamente destituída dos valores sociais e religiosos que envolvem o tema do erotismo, sobretudo quando se refere aos desejos femininos.

Todavia, é preciso que se destaque também a afirmação do sujeito poético como ser desejante, enfatizado pela quase ausência da menção ao "outro", ao amante (ele surge nos versos "Dentro, em nós, mais se ateia, / ao contato febril do lábio amado e amante", sempre junto do eu lírico), visto que o poema se constrói sobre as sensações causadas pelo beijo de amor, algo que "entender só pode o ente que ama, que adora", como se prescindisse do amor do outro, em uma situação em que mais importa o sentimento de quem recebe o beijo. Interessa notar como uma relação existente apenas pelo contato entre dois indivíduos transforma-se em uma experiência expressada literariamente através de um eixo marcadamente individual, em que se afirma a volúpia centrada no eu lírico. A experiência do beijo ainda parece constituir uma espécie de aprendizado e conhecimento que complementa o sujeito lírico: os versos "semente, que a vermelha / flor da luxúria vem plantar sobre o maninho / solo da alma [...]" referem-se à luxúria como elemento que transforma a "alma" anteriormente estéril, sugerindo a carência que configurava 
esse sujeito sem os elementos sensórios proporcionados pelo beijo - o erotismo, então, torna-se parte fundamental da construção dessa identidade afirmativa que o associa com o discurso poético quando se refere ao "áureo poema" e ao "original pomo da árvore da alma". Se o livre acesso ao erotismo era algo ainda interdito para as mulheres, afirmar a sua necessidade era subversivo e implicava o esforço de romper com as pressões sociais contrárias, advindo disso, talvez, a "hesitação", presente no poema através da necessidade constante de assinalar oposições entre corpo e alma, revelando o ímpeto por mesclar os dois polos, e a relativa depreciação da volúpia, anexada à igualmente forçosa asserção de uma subjetividade desejante, configurada pelas sensações eróticas expressadas liricamente. A edificação de tal identidade, portanto, está atrelada à da subjetividade poética, mesclando erotismo e palavra, componentes necessários para fazer nascer a vida que faltava no "maninho solo da alma": afirmar e reivindicar o direito feminino de sentir e desejar os corpos é também o de escrever e o de expressar-se, buscando encontrar, finalmente, uma subjetividade própria, ainda que cindida e conflitante, não mais totalmente limitada pelos modelos paradigmáticos impingidos às mulheres pela socialização.

Juana de Ibarbourou refere-se também à sensualidade evocada pelo beijo em "Las cuatro alas de abeja":

He vuelto de la cita con cuatro alas de abejas Prendidas en los labios. Cuatro alas de abejas Doradas y bermejas.

¡Milagro como el de la barba de Dionisos, El dios de acento dulce! La barba de Dionisos Que tenía cuatro alas de abeja en vez de rizos.

Tus labios en mis labios derramaron su miel y brotaron las alas. Derramaron su miel y tuve las dulzuras de un panal en la piel.

No riáis. Las cuatro alas de abeja no se ven, Mas las siento en la boca. Las alas no se ven, Mas a veces, iprodigio!, vibran hasta en mi sien.

Y más adentro aún. Las dulces alas vibran Hasta en mi corazón. Las dulces alas vibran Y a mi alma de toda angustia y pena libran.

Mas si un día dejaran de aletear y zumbar... Si se hicieran ceniza... Si cesara el zumbar De las alas que hiciste en mis labios brotar... 
¡Qué tristeza de muerte! ¡Qué alas negras de queja

Brotarían entonces! ¡Qué alas negras de queja

En lugar de las alas transparentes de abeja! (IBARBOUROU, 2003, p.131)

Embora o erotismo não esteja metaforicamente explícito como no poema de Gilka Machado, o beijo imprime sensações que perduram no eu lírico como a ebulição de sentidos comparados com o bater das asas da abelha, fazendo-se referência ao deus Dioniso, de amplas e complexas atribuições e origens, mas normalmente relacionado com o êxtase, a celebração orgíaca ${ }^{2}$, o vinho, os frutos e a renovação das estações do ano. Ao mesmo tempo, o deus está, em algumas das versões para o seu nascimento, conectado às abelhas, uma vez que, conforme observa Carlson (2015, p. 41), Apolônio de Rodes narra a história em que Dioniso, após ser retirado da coxa de seu pai, Zeus, teria sido enviado por Hermes a Macris a fim de que esta o alimentasse com mel. A referência a Dioniso reúne em si as várias apreciações acerca da sensualidade do beijo, acentuada pela doçura sugerida pelo mel das abelhas, que tanto caracterizam o mito de nascimento da divindade como simbolizam o desfrute absoluto da experiência amorosa. De acordo com Jean Chevalier e Alain Gheerbrant (1986, p.421, tradução nossa), desde uma perspectiva sobre os aspectos primitivos de Dioniso, ele "simboliza a ruptura das inibições, das repressões, dos rechaços. É uma das figuras nietzchianas da vida, oposta ao prudente aspecto apolíneo", podendo desvelar, assim, o teor libertador do poema: como na poesia da escritora brasileira, expressar as sensações de deleite sensual é ultrapassar os limites estabelecidos para o espaço feminino de atuação; caminho mais extensamente percorrido pelo sujeito lírico, que afirma o profundo significado da experiência do beijo e seu caráter transformador.

Retomando a simbologia da abelha, pode-se destacar sua ligação com a poesia e o discurso, com o dom da palavra que se transfere para o artista, o que se

\footnotetext{
2 Junito de Souza Brandão (1987, p. 136) observa que nas Antestérias, festa sagrada do vinho, os participantes, embriagados, dançavam e cantavam intensamente até atingirem um estado de semiconsciência, "saindo de si" pelo processo de êxtase. "Esse sair de si significava uma superação da condição humana, [...] a descoberta de uma liberação total, a conquista de uma liberdade e de uma espontaneidade que os demais seres humanos não podiam experimentar. Evidentemente, essa superação da condição humana e essa liberdade, [...] constituíam [...] uma libertação de interditos, de tabus, de regulamentos e de convenções de ordem ética, política e social [...]". Isso explicaria a forte adesão de mulheres às festas de Dioniso. A menção a essa divindade, por conseguinte, demonstra o interesse de Juana de Ibarbourou em aludir ao transbordamento da sensualidade a partir do beijo, momento em que o eu lírico não se contém dentro das barreiras sociais moralizantes.
} 
traduz pela metáfora das "quatro asas de abelhas" usada pela poetisa e que inclusive merece seu comentário - "No riáis": parece haver uma necessidade de explicitar o uso da expressão lírica, que recria as sensações causadas pelo beijo por meio da recuperação e do conhecimento da tradição literária, não se tratando, portanto, de uma simples afirmação supostamente ilógica, como a crítica literária escrita majoritariamente por homens poderia atribuir aos textos de autoria feminina. O eu lírico parece reivindicar a atenção e a justa apreciação de sua poesia, explicando a urgência de expressar poeticamente a importância fundamental do seu corpo e do que causam nele os estímulos sensórios, ao mesmo tempo em que assume uma identidade literária - a autoria dos versos e o direito de escrevê-los a despeito do aparato repressor e censório simbolizado pelo solicitado "no riáis". A sensação prazerosa, que se incide no sujeito desde os lábios, aprofunda-se cada vez mais até chegar às têmporas, ao coração e à alma, onde se reveste do poder de livrá-lo do sofrimento e da angústia: o "zumbido" das asas das abelhas pode, assim, em seu sentido ambivalente de frenesi sensual e aptidão para a literatura (como nas lendas clássicas, as abelhas "pousaram" nos lábios do eleito, dando-lhe o talento da escrita e do discurso), aludir à mescla entre o corpo e o discurso poético em processo de construção (veja-se a gradação dos planos de atuação da vibração das asas dos insetos - boca, têmpora, coração, alma), de forma semelhante à estratégia utilizada no poema de Gilka Machado.

Jorge Rodríguez Padrón (2003, p.40, tradução nossa) observa que, na poesia de Ibarbourou, "o corpo é sempre [...] o espaço de debate da experiência existencial; ele mesmo oferece a energia necessária a essa palavra em liberdade que opta por dizê-la sem dissimulação e nem vergonha. É algo consciente e voluntariamente aceito [...]". Em "Las cuatro alas de abeja", é através do corpo que se afirma a necessidade intrínseca de expressão poética para um eu lírico que parece buscar libertar-se das amarras sociais sutilmente expostas pelo "no riáis". Cabe notar que nas duas últimas estrofes, a ideia do cessar das asas "brotadas" nos lábios conduz à aniquilação ("si se hicieran ceniza") e à tristeza ("alas negras de queja"), novamente comparando-se o zumbir sensual do beijo e o alvoroço da palavra nos lábios, isto é: caso desapareça essa possibilidade da expressão da palavra poética (repressão da escrita literária) ou caso sumam os estímulos sensuais que os beijos do outro (a proibição da fruição erótica) fizeram nascer nos lábios do sujeito lírico, ele ficará ensombrecido, conforme conotam as modificações das cores relativas às asas das 
abelhas - douradas e vermelhas na primeira estrofe (ideia que pode estar relacionada com a volúpia e com a riqueza de sentimentos oriundas da sensação física do beijo), transparentes na última estância (uma referência, porventura, à manifestação do discurso lírico sem impedimentos), contrapostas às negras asas do pesar (ausência de luz e de vida).

Embora a sensação erótica do beijo não apresente conotações negativas, como no poema "Beijo", de Gilka Machado, visto que o sofrimento apenas se instalaria na hipótese da interrupção da experiência poética/corporal, cabe notar que, no caso da poesia de lbarbourou, a presença do outro é imprescindível, pois é dos lábios dele que brota o mel provocador dos estímulos sensoriais. Ao contrário do que se verifica na composição da poetisa brasileira, explicitam-se tanto o encontro com esse "tu" ("He vuelto de la cita con cuatro alas de abejas") quanto se ressalta que essa segunda pessoa é a "fonte" para o elemento que faz vibrarem as asas nos lábios do eu lírico. O "interlocutor" do poema parece representar o outro necessário para incitar as sensações eróticas do beijo e aquele que propicia a expressão lírica da subjetividade constituída em um processo gradativo de internalização e afirmação das "vibrações" sensuais transfiguradas em "voo" literário. Novamente corpo e palavra se unem na metáfora das "asas" das abelhas, que conotam a criação erigida a partir do impulso duplo do sentir e fruir o corpo e do escrever e expressar, remetendo à simbologia do inseto como aquele que pode cruzar as fronteiras entre as esferas divina e terrena: a menção a Dioniso e seu "acento dulce" refere-se ao poder do discurso, configurado pela doçura da voz divina, transportada ao eu lírico por meio das sensações do beijo comparadas à vibração das asas.

A oposição de cariz mais católico simbolizada pela figura ambivalente do corpo da abelha, entre o corporal (a parte inferior que contém o ferrão) e o espiritual (a porção superior da estrutura física do inseto), marcante em "Beijo", de Machado, por exemplo, não se verifica em "Las cuatro alas de abeja", uma vez que parece não haver censura do sujeito lírico com relação à sensualidade encerrada na experiência do beijo, referindo-se, ao contrário, à figura da divindade clássica associada precisamente aos deleites sexuais e ao rechaço do equilíbrio racional. Todavia, apesar de que a satisfação sensual é usufruída em sua faceta positiva, sem se dar conta de uma negatividade inerente, como no caso do poema de Gilka Machado, o de Juana de Ibarbourou parece marcar uma origem externa ao próprio sujeito lírico: as sensações causadas pelo beijo e seus desdobramentos originam-se de outro 
lábio que "derramaron su miel", sendo imprescindível um "tu" que faz brotar as citadas asas, ao passo que o poema da poetisa carioca estava mais centrado na própria experiência do eu lírico, aprofundando o processo de construção de uma subjetividade afirmativamente desejante como fenômeno majoritariamente individual.

\section{Considerações finais}

Retomando o contexto sociocultural que constituiu o paradigma de socialização feminina vigente no período em que Gilka Machado e Juana de Ibarbourou escreveram suas primeiras obras poéticas, pode-se compreender a importância dos poemas no sentido de romper com as limitações impostas à produção literária de autoria feminina. A busca pela asserção de uma subjetividade poética por meio da experiência erótica e das sensações físicas provocadas pelo contato direto com o outro, revisitando e reapropriando-se de uma complexa simbologia literária, configura um processo marcado por ambiguidades e conflitos. Conforme observam Gilbert e Gubar (2000, p.73-74, tradução nossa), "[...] mulheres no patriarcado tradicionalmente cultivaram notas de aquiescência a fim de obter liberdade para viver suas vidas sob seus próprios termos, mesmo que somente na privacidade de seus próprios pensamentos", de modo que frequentemente demonstram submissão e, ao mesmo tempo, subversão aos modelos sociais estabelecidos. Machado, dessa forma, constrói um eu lírico centrado nas sensações individuais incitadas pelo beijo, desenvolvendo o poema a partir de inúmeras metáforas que perfazem a volúpia pelos estímulos visuais, auditivos e tácteis, ainda que também assinalem a ambivalência do desejo sensual, revelando o confronto entre as contrapartes espiritual e corporal, culminando tanto em positivas quanto em negativas percepções acerca do erotismo. Por outro lado, o poema de Ibarbourou, embora se concentre nos aspectos "doces" do beijo e da sensualidade envolvida, faz sobressair a importância do elemento externo que infunde as sensações e provoca a expressão lírica, enfraquecendo, de certa maneira, a força individual para a definição e construção da percepção do próprio corpo (e seus desdobramentos no que concerne à relevância disso na edificação de um eu poético afirmativo), marcante no poema de Gilka Machado.

Importa notar como as poetisas se apropriaram das simbologias da vespa e da abelha, enfatizando elementos relacionados com os desejos eróticos, cada qual à 
sua maneira, mas desnudando-as de conteúdos que conotavam um ponto de vista depreciativo sobre as mulheres, como a ideia de que elas eram um "mal" necessário (sugavam os recursos sexuais e financeiros dos homens, apesar de imprescindíveis para a perpetuação da linhagem e da família - semelhante à relação das abelhas com os zangões dentro da colmeia). A retomada do tópico literário, desse modo, pode instaurar um ponto de ruptura no modelo estabelecido a fim de permitir sua recriação desde a perspectiva da autoria feminina. Buscar compreender esses sinais de contato entre escritoras pertencentes a contextos socioculturais semelhantes pode constituir uma tentativa, entre inúmeras outras possibilidades de leitura, de analisar a importância de obras frequentemente pouco estudadas no âmbito acadêmico, avaliando a maneira como elas lograram produzir poesia em meio a uma crítica muitas vezes condescendente ou cerceadora, revelando-se, assim, muito de um discurso literário esquecido ou posto à margem.

\section{Referências}

ARAÚJO, Rosa Maria Barboza de. A vocação do prazer. a cidade e a família no Rio de Janeiro republicano. 2. ed. Rio de Janeiro: Rocco, 1995.

BECKER, Udo. The Continuum encyclopedia of symbols. Trad. Lance W. Garmer. New York: Continuum, 2000.

BLIXEN, Carina. El desván del novecientos. Mujeres solas: Delmira Agustini, María Eugenia Vaz Ferreira. 2. ed. Montevideo: Ediciones del Caballo Perdido, 2014.

BRANDÃO, Junito de Souza. Mitologia Grega. Vol. II. Petrópolis, RJ: Vozes, 1987.

CARLSON, Rachel D. The Honey Bee and Apian Imagery in Classical Literature. 2015. 159 p. Dissertation (Doctor of Philosophy) - University of Washington, 2015.

CHEVALIER, Jean; GHEERBRANT, Alain. Diccionario de los símbolos. Barcelona: Editorial Herder, 1986.

GILBERT, Sandra M. e GUBAR, Susan. The madwoman in the attic: the woman writer and the nineteenth-century literary imagination. 2. ed. New Haven; London: Yale University Press, 2000.

GOTTLIEB, Nádia Battella. Com Dona Gilka Machado, Eros pede a palavra (Poesia erótica feminina brasileira nos inícios do século XX). Polímica. Revista de Crítica e Criação, São Paulo, n. 4, p. 23-47, 1982. 
IBARBOUROU, Juana de. Las lenguas de diamante. Raíz salvaje. Edición de Jorge Rodríguez Padrón. 2. ed. Madrid: Cátedra, 2003.

MACHADO, Gilka. Poesias Completas. Rio de Janeiro: Cátedra, 1978.

MALUF, Marina; MOTT, Maria Lúcia. Recônditos do mundo feminino. In: SEVCENKO, Nicolau (Org.). História da vida privada no Brasil. República: da Belle Époque à Era do Rádio. v. 3. 10. reimpr. São Paulo: Companhia das Letras, 2012, p.367-421.

PAIXÃO, Sylvia. A fala-a-menos: a repressão do desejo na poesia feminina. Rio de Janeiro: Numen, 1991.

RAGO, Margareth. Trabalho feminino e sexualidade. In: DEL PRIORE, Mary. (Org.). História das mulheres no Brasil. São Paulo: Contexto, 2011, p. 578-606.

RODRÍGUEZ PADRÓN, Jorge. Introducción. In: IBARBOUROU, Juana de. Las lenguas de diamante. Raíz salvaje. Edición de Jorge Rodríguez Padrón. 2. ed. Madrid: Cátedra, 2003, p. 13-117.

SÁINZ DE MEDRANO, Luis. La poesía en el siglo XX: del posmodernismo a las vanguardias. In: BARRERA, Trinidad. (Coord.). Historia de la literatura hispanoamericana. Tomo III. Siglo XX. Madrid: Cátedra, 2008, p. 483-497.

SAPRIZA, Graciela. La hora de la eugenesia: las feministas en la encrucijada. In: GÓMEZ-FERRER, G.; CANO, G.; BARRANCOS, D.; LAVRIN, A. (Coord.). Historia de las mujeres en España y América Latina. v.III. 2. ed. Madrid: Cátedra, 2008, p.889-913.

SOARES, Angélica. A paixão emancipatória: vozes femininas da liberação do erotismo na poesia brasileira. Rio de Janeiro: DIFEL, 1999.

STILLWELL, Kristen Mary Elizabeth. The gift of the bee-poet: bee symbolism in H.D.'s poetry and prose. 2012. 99 p. Thesis (Master of Arts) - Faculty of the Graduate School, University of North Carolina, Greensboro, 2012.

TORRES, María Inés de. ¿La nación tiene cara de mujer? Mujeres y nación en el imaginario letrado del Uruguay del siglo XIX. Bernal: Universidad Nacional de Quilmes, 2013.

WERNESS, Hope B. The continuum encyclopedia of animal symbolism in art. New York: Continuum, 2006. 